\title{
Histiocytoid cardiomyopathy
}

INSERM

\section{Source}

INSERM. (1999). Orphanet: an online rare disease and orphan drug data base.

Histiocytoid cardiomyopathy. ORPHA:137675

Histiocytoid cardiomyopathy is an arrhythmogenic disorder characterised by

cardiomegaly, severe cardiac arrhythmias or sudden death, and the presence of histiocyte-like cells within the myocardium. 